\title{
ELECTRONIC WORD OF MOUTH ACTIVITIES IN THE HOTEL INDUSTRY
}

\author{
Emel Yarimoglu 1 \\ Tugrul Gunay ${ }^{2}$ \\ Yigit Sebahattin Bozkurt ${ }^{3}$
}

DOI: https://doi.org/10.31410/ITEMA.S.P.2019.125

\begin{abstract}
In this study, we focused on analyzing customers' electronic word of mouth activities in third-party booking websites which consist of detailed reviews, suggestions, and complaints about hotels. It was included to the research Booking.com, TripAdvisor, Trivago, Agoda, Hotels.com, Expedia, and Kayak as third-party booking websites. The aim of the study was to analyze the relationships among electronic word of mouth activities, trust, and loyalty. The field study was conducted with 120 university students chosen by convenience sampling. Data were collected by using online survey in North Cyprus during March, 2019. Data were analyzed via confirmatory factor analysis and structural equation modelling. In findings, it was found out that trust has a positive effect on loyalty, loyalty has a positive effect on electronic word of mouth intensity, and electronic word of mouth intensity had a positive effect on positive electronic word of mouth activities. Interestingly, it was not found out a significant relationship between loyalty and positive electronic word of mouth. Implications for booking websites and hotel industry were interpreted, and limitations and further research suggestions were advised.
\end{abstract}

Keywords: Booking Websites, Electronic Word of Mouth Intensity, Electronic Positive Word of Mouth, e-WOM, eWOM.

\section{INTRODUCTION}

I nformation about products or services has become the key point that affects consumer behavior. Mostly before buying, customers prefer asking to their friends or relatives about the product or service that they intended to buy. With the developments in information technology, spread of knowledge has been raising day by day. Electronic word of mouth (e-WOM) is the solution who seeks advices and suggestions from people who they trust. Singh (2000) emphasized that e-WOM is a perfect mean to deliver to others about what customers have experienced during their shopping or visiting. Goyette et al. (2010) analyzed e-WOM activities into three parts such as e-WOM intensity, positive e-WOM, and negative e-WOM. e-WOM intensity showed the frequency level of speaking about the company, positive e-WOM consisted of the positive past experiences about the company, and on the contrary of this, negative e-WOM contained negative past experiences about the company.

In service industries, online customer reviews, which are one of the mostly used types of e-WOM activities (Yarimoglu and Ozelturkay, 2017), were paid great importance by prospect customers since services are intangible and prospect customers would like to get more information before using this service in order not to be dissatisfied. In the hotel industry, particularly in booking websites and

\footnotetext{
1 Yasar University, Faculty of Business, Department of Business Administration, Universite Cad. N:37-39 35100 Bornova-Izmir/Turkey

2 Eastern Mediterranean University, Faculty of Tourism, Gazimagusa, Turkey

3 Adnan Menderes University, Faculty of Tourism, Aydın/Turkey
} 
social media channels, online customer reviews consisting of suggestions, advices, and complaints were created by former customers to affect prospect customers' intentions of buying in a good way or bad way. Third-party booking websites such as Booking.com, TripAdvisor, Trivago, Agoda, Hotels. com, Expedia, and Kayak were the general platforms that former customers wrote about their positive or negative experiences. The e-WOM activities on these websites also show the satisfaction or dissatisfaction levels of the customers from the hotels that they have stayed and experienced.

In literature, mostly the effects of e-WOM on consumers' buying behavior were investigated (Park and Lee, 2008; Amblee and Bui, 2011; Ladhari and Michaud, 2015; Babic Rosari et al., 2016). However, in this study, it was aimed to analyze the effects of trust, which was found as one of the antecedents of loyalty (Chaudhuri and Holbrook, 2001; Munuera-Aleman 2003), and loyalty on e-WOM activities. Within this aim, the hypotheses were developed as follow:

Hypothesis One: Trust positively influences loyalty.

Hypothesis Two: Loyalty positively influences e-WOM intensity.

Hypothesis Three: Loyalty positively influences positive e-WOM.

Hypothesis Four: e-WOM intensity positively influences positive e-WOM.

The research model of the study was shown in Figure 1 below.

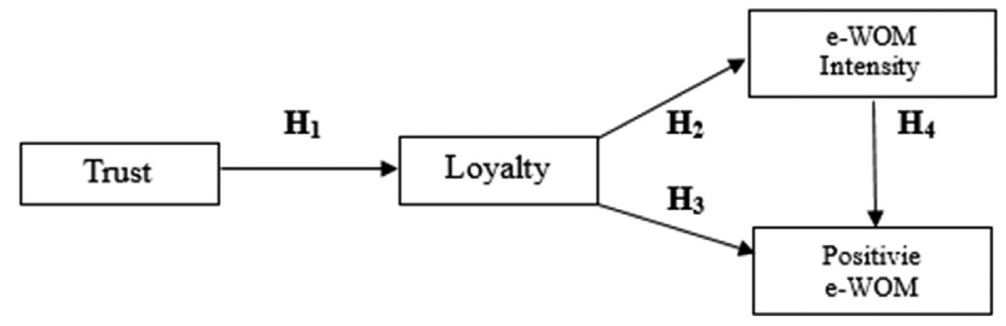

Figure 1. Research model

\section{RESEARCH METHODOLOGY}

Data were collected from university students by using online survey. The questionnaire was generated by modified scales taken from the literature. Trust scale was taken from Munuera-Aleman et al. (2003) and adapted to the research with four items. Loyalty scale, which was a four-item scale, was modified from Munuera-Aleman et al. (2003). e-Wom scale, which had nine items, was adapted from Goyette et al. (2010). The field study was conducted in North Cyprus, Eastern Mediterranean University in March, 2019. Total 120 international students chosen by convenience sampling participated in the research. They answered the questions in the survey based on their last hotel experience. Data were analyzed by confirmatory factor analysis and the hypotheses were tested via structural equation modelling.

\section{FINDINGS}

The undergraduate students from Department of Tourism were participated in the research. The demographic characteristics of participants were shown in Table 1 below.

According to the Table 1, the great majority of the participants were male, the majority of the students are between 22 and 25 years old. Most of them were from Turkish Republic of Northern Cyprus. They have taken monthly allowance between 2000 and 3999 TRY. When the research was conducted, 1 USD (USA dollar) equaled to 5.50 TRY (Turkish Lira). 
Confirmatory Factor Analysis (CFA) was implemented to the scales. After necessary modifications, one item from Trust scale (T4), one item from Loyalty scale (L4), and one item from Positive e-WOM scale (PW6) were deleted. The results of CFA in Table 2 below showed that total 14 observed variables loaded on their respective dimensions, and they provided a good fit $\left(\chi^{2} /\right.$ $\mathrm{df}=1.347$; GFI=0.894; $\mathrm{AGFI}=0.844 ; \mathrm{CFI}=0.914 ; \mathrm{RMSEA}=0.054)$ (Schumacker and Lomax, 2004).

Table 1. Demographic characteristics

\begin{tabular}{|l|l|c|c|}
\hline \multicolumn{2}{|c|}{ Demographics } & Frequency & Percent \\
\hline \multirow{4}{*}{ Gender } & Female & 48 & 40 \\
\cline { 2 - 4 } & Male & 72 & 60 \\
\cline { 2 - 4 } & Total & 120 & 100 \\
\hline \multirow{5}{*}{ Nationality } & $18-21$ & 34 & 28.3 \\
\cline { 2 - 4 } & $22-25$ & 57 & 47.5 \\
\cline { 2 - 4 } & $26-29$ & 29 & 24.2 \\
\cline { 2 - 4 } & Total & 120 & 100 \\
\hline \multirow{5}{*}{ Allowance } & Northern Cyprus & 63 & 52.5 \\
\cline { 2 - 4 } & Iran & 26 & 21.7 \\
\cline { 2 - 4 } & Nigeria & 20 & 16.7 \\
\cline { 2 - 4 } & Ukraine & 11 & 9.2 \\
\cline { 2 - 4 } & Total & 120 & 100 \\
\hline & $2000-3999$ TRY & 64 & 53.3 \\
\cline { 2 - 4 } & $4000-5999$ TRY & 46 & 38.3 \\
\cline { 2 - 4 } & $6000-7999$ TRY & 10 & 8.3 \\
\cline { 2 - 4 } & Total & 120 & 100 \\
\hline
\end{tabular}

Table 2. Results of factor analysis

\begin{tabular}{|l|c|}
\hline \multicolumn{1}{|c|}{ Item } & $\begin{array}{c}\text { Factor } \\
\text { Loading }\end{array}$ \\
\hline Trust (T) & 0.763 \\
\hline T1. This hotel meets my expectations. & 0.289 \\
\hline T2. I feel confidence in this hotel. & 0.535 \\
\hline T3. This hotel never disappoints me. & 0.326 \\
\hline Loyalty (L) & 0.502 \\
\hline L1. I consider myself to be loyal to this hotel. & 0.899 \\
\hline L2. Only under extreme circumstances, I would consider visiting a different hotel. & \\
\hline L3. If this hotel was full, I would go somewhere else. & 0.297 \\
\hline e-WOM Intensity (WI) & 0.604 \\
\hline WI1. I spoke of this hotel much more frequently than about any other hotels. & 0.824 \\
\hline WI2. I spoke of this hotel much more frequently than about companies of any other type. & 0.534 \\
\hline WI3. I spoke of this hotel to many people around me. & 0.752 \\
\hline Positive e-WOM (PW) & 0.717 \\
\hline PW1. I recommended this hotel. & 0.372 \\
\hline PW2. I speak of the good sides of this hotel. & 0.371 \\
\hline PW3. I am proud to say to others that I am the customer of this hotel. \\
\hline PW4. I strongly recommend people buy different services from this hotel. & \\
\hline PW5. I mostly say positive things to others about this hotel. &
\end{tabular}

Structural equation modeling was used to test the model and hypotheses. Model fit well $(\chi 2$ $/ \mathrm{df}=1,316 ; \mathrm{GFI}=0,893 ; \mathrm{AGFI}=0,846 ; \mathrm{CFI}=0,919 ; \mathrm{RMSEA}=0,052)$. The results were shown in Table 3 below. 
Table 3. Results of path analysis

\begin{tabular}{|l|c|c|c|c|}
\hline \multicolumn{1}{|c|}{ Hypothesis } & S.E. & C.R. & p & Result \\
\hline $\mathrm{H}_{1}: \mathrm{T} \rightarrow \mathrm{L}$ & 0.110 & 2.393 & 0.01 & Supported \\
\hline $\mathrm{H}_{2}: \mathrm{L} \rightarrow \mathrm{WI}$ & 0.202 & 1.897 & 0.05 & Supported \\
\hline $\mathrm{H}_{3}: \mathrm{L} \rightarrow \mathrm{PW}$ & 0.195 & -0.494 & 0.62 & Not Supported \\
\hline $\mathrm{H}_{4}: \mathrm{WI} \rightarrow \mathrm{PW}$ & 0.498 & 2.453 & 0.01 & Supported \\
\hline
\end{tabular}

Except $\mathrm{H}_{3}$, other three hypotheses were found as significant. $\mathrm{H}_{1}$ that predicted the effects of trust on loyalty was supported $(\beta=0.628) . \mathrm{H}_{2}$ that predicted the effects of loyalty on e-WOM intensity was supported $(\beta=0.398) . \mathrm{H}_{3}$ that predicted the effects of loyalty on positive e-WOM was not supported. $\mathrm{H}_{4}$ that predicted the effects of e-WOM intensity on positive e-WOM was supported $(\beta=0.726)$.

\section{CONCLUSION}

The study investigated the effects of trust and loyalty on e-WOM intensity and positive e-WOM. In the results, firstly, trust affected loyalty. It was approved in literature. In the study of Munuera-Aleman et al. (2003), it was found out that trust affected loyalty $(\beta=0.45)$. Second, it was found out that loyalty had low impact on e-WOM intensity. Third, e-WOM intensity directly affected positive e-WOM activities. And lastly, it was found out that loyalty did not affect positive e-WOM. This result was interesting since it was known that loyal customers usually say positive things regarding companies. The link between loyalty and positive e-WOM activities should be revisited again.

Based on findings, it can be said that the biggest impact was found between e-WOM intensity and positive e-WOM activities. It showed that the more e-WOM intensity increases, the more positive e-WOM raises. The second biggest influence was found between trust and loyalty. It showed that if trust increases, loyalty increases as well. The weakest effect was found between loyalty and e-WOM intensity. And, no significant relationship was found between loyalty and positive e-WOM.

In the hotel industry, suggestions of other customers are one of the important sources for travelers. Many people search online before travelling. Since third-party booking websites are the ones which were used much during decision-making process, they should create more contents to encourage customers who will involve e-WOM activities. Trust and loyalty were the key factors that affect e-WOM intensity. So, it is important especially for booking websites to create trustful relationships with their customers. After building trust, satisfied and loyal customers will create e-WOM activities on by own. This led booking websites to produce better and trustful advices and suggestions regarding hotels in the tourism industry.

\section{LIMITATIONS \& FUTURE RESEARCH SUGGESTIONS}

There were some limitations in the research. First, the research involved all types of third-party booking websites such as Booking.com, TripAdvisor, Trivago, Hotels.com, Agoda, Kayak, and Expedia. It was advised to researchers to choose one specific website, then conduct a study with the customers of this website.

Second, social media channels are also good sources for online customer reviews. In further studies, customers' e-WOM activities in different social media channels such as Instagram and 
Facebook should be investigated. Also, the effects of influencers and influencer marketing could be included to the research.

Third, in this study, only positive e-WOM activities were included to the research. However, previous studies showed that negative e-WOM affects customers more than positive e-WOM (Park and Lee, 2009), and the credibility of negative e-WOM was higher than positive e-WOM (Lee and Koo, 2012). It was advised to scholars to search about the effects of negative e-WOM and analyze them within complaint management.

Lastly, there were some methodological limitations in the research such as sample consisted of university students and only one university was included to the research. In future studies, it was advised to conduct this study with bigger and older samples.

\section{REFERENCES}

Amblee, N., \& Bui, T. (2011). Harnessing the influence of social proof in online shopping: The effect of electronic word of mouth on sales of digital microproducts. International journal of electronic commerce, 16(2), 91-114.

Babić Rosario, A., Sotgiu, F., De Valck, K., \& Bijmolt, T. H. (2016). The effect of electronic word of mouth on sales: A meta-analytic review of platform, product, and metric factors. Journal of Marketing Research, 53(3), 297-318.

Chaudhuri, A., \& Holbrook, M. B. (2001). The chain of effects from brand trust and brand affect to brand performance: the role of brand loyalty. Journal of marketing, 65(2), 81-93.

Goyette, I., Ricard, L., Bergeron, J., \& Marticotte, F. (2010). e-WOM Scale: word-of-mouth measurement scale for e-services context. Canadian Journal of Administrative Sciences/ Revue Canadienne des Sciences de l'Administration, 27(1), 5-23.

Ladhari, R., \& Michaud, M. (2015). eWOM effects on hotel booking intentions, attitudes, trust, and website perceptions. International Journal of Hospitality Management, 46, 36-45.

Lee, K. T., \& Koo, D. M. (2012). Effects of attribute and valence of e-WOM on message adoption: Moderating roles of subjective knowledge and regulatory focus. Computers in $\mathrm{Hu}-$ man Behavior, 28(5), 1974-1984.

Munuera-Aleman, J. L., Delgado-Ballester, E., \& Yague-Guillen, M. J. (2003). Development and Validation of a Brand Trust Scale. International Journal of Market Research, 45(1), $1-18$.

Park, D. H., \& Lee, J. (2008). eWOM overload and its effect on consumer behavioral intention depending on consumer involvement. Electronic Commerce Research and Applications, 7(4), 386-398.

Park, C., \& Lee, T. M. (2009). Information direction, website reputation and eWOM effect: A moderating role of product type. Journal of Business research, 62(1), 61-67.

Singh, D. (2000). Electronic word of mouth. Paradigm, 4(2), 1-11.

Yarimoglu, E. K., \& Ozeltürkay, E. Y. (2017). Examining online customer reviews by aidmsas hierarchy of effects model: a research on university students. Pazarlama ve Pazarlama Araştırmaları Dergisi, 10(20), 135-153. 